\title{
A Study on the Interplay between the Constructs of Quality of Work life: With Special Reference to IT Professionals in Bangalore City
}

\author{
M. Swapna ${ }^{1,2} \&$ S. Gomathi ${ }^{3}$ \\ ${ }^{1}$ Research Scholar(EPT), VIT Business School, VIT University, Vellore, India \\ ${ }^{2}$ Sambhram Academy of Management Studies, Bangalore, India \\ ${ }^{3}$ OB \& HR Division, VIT Business School, VIT University, India \\ Correspondence: M. Swapna, No.225, 4th Main, 4th Cross, MSR Nagar, Mathikere, Bangalore, 54, Karnataka, \\ India. E-mail: roses4swapna@yahoo.co.in
}

Received: December 23, 2012 Accepted: May 8, 2013 Online Published: June 28, 2013

doi:10.5539/ass.v9n9p107 URL: http://dx.doi.org/10.5539/ass.v9n9p107

\begin{abstract}
It is almost impossible today to pick up a newspaper or news-magazine without finding a reference to quality of work/working life. In the search for improved productivity, manager and executives alike are discovering the important contribution of QWL. QWL entails the design of work systems that enhance the working life experiences of organizational members, thereby improving commitment and motivation for achieving organizational goals. Most, often, this has been implemented through the design of jobs that afford workers more direct control over their immediate work environment. It also refers to the favorableness or unfavorableness of a job environment for people. The basic purpose is to develop work environments that are excellent for people as well as for the economic health of the organization. A better quality of work life for employees leads to a higher productivity for the employer. Quality in work is important for individuals, but also for growth, employment and a sustainable and competitive economy. "When organization have addressed the issue of quality of working life, they have always achieved great productivity breakthroughs" (Rosow). This research paper elicits the inter play between the constructs of Quality of Worklife (QWL) in IT Industry and the results are presented hypothetically.
\end{abstract}

Keywords: quality of work life, constructs \& items

\section{Introduction}

QWL refers to the degree to which a person enjoys the important possibilities of his/her life. Possibilities result from the opportunities and limitations each person has in his/her life and reflect the interaction of personal and environmental factors. Enjoyment has two components: the experience of satisfaction and the possession or achievement of some characteristic, as illustrated by the expression: "She enjoys good health." Three major life domains are identified: Being, Belonging, and Becoming. The conceptualization of Being, Belonging, and Becoming as the domains of quality of life were developed from the insights of various writers.

The Being domain includes the basic aspects of "who one is" and has three sub-domains. Physical being includes aspects of physical health, personal hygiene, nutrition, exercise, grooming, clothing, and physical appearance. Psychological being includes the person's psychological health and adjustment, cognitions, feelings, and evaluations concerning the self, and self-control. Spiritual being reflects personal values, personal standards of conduct, and spiritual beliefs which may or may not be associated with organized religions.

Belonging includes the person's fit with his/her environments and also has three sub-domains. Physical Belonging is defined as the connections the person has with his/her physical environments such as home, workplace, neighborhood, school and community. Social Belonging includes links with social environments and includes the sense of acceptance by intimate others, family, friends, co-workers, and neighborhood and community. Community belonging represents access to resources normally available to community members, such as adequate income, health and social services, employment, educational and recreational programs and community activities.

Becoming refers to the purposeful activities carried out to achieve personal goals, hopes, and wishes. Practical Becoming describes day-to-day actions such as domestic activities, paid work, school or volunteer activities and seeing to health or social needs. Leisure Becoming includes activities that promote relaxation and stress 
reduction. These include card games, neighborhood walks and family visits, or longer duration activities such as vacations or holidays. Growth Becoming activities promote the improvement or maintenance of knowledge and skills.

\subsection{The Elements in a QWL Program Include Many Constructs Like}

1) Open communication

2) Equitable reward system

3) A concern for employee job security

4) Participation in job design - job enrichment \& organisational design

5) Employee skill development

6) Reduction of occupational stress

7) Good employer-employee relations

8) A challenging job

9) More opportunity for growth

10) Encouraging creativity and innovation in employees

11) Alternate work schedule

12) Workers participation in management

13) Supportive leadership

14) Autonomy and delegation of authority

15) An atmosphere based on fairness, integrity and trust

16) Continuous development of employees

17) Good appraisal system

18) Recognition programs

19) Employee benefits

20) Profit sharing

21) Pension rights

22) Quality Circles

23) Ergonomics

24) Socio-technical Systems

\subsection{Industry Profile}

Information Technology (IT) industry in India is one of the fastest growing industries. Indian IT industry has built up valuable brand equity for itself in the global markets. IT industry in India comprises of software industry and information technology enabled services (ITES), which also includes business process outsourcing (BPO) industry. India is considered as a pioneer in software development and a favorite destination for IT-enabled services.

Today, Indian IT companies such as Tata Consultancy Services (TCS), Wipro, Infosys, and HCL are renowned in the global market for their IT prowess. Some of the major factors which played a key role in India's emergence as key global IT player are:

1) Indian Education System;

2) High Quality Human Resource;

3) Competitive Costs;

4) Infrastructure Scenario;

In the last few years Indian IT industry has seen tremendous growth. Destinations such as Bangalore, Hyderabad and Gurgaon have evolved into global IT hubs. Several IT parks have come up at Bangalore, Hyderabad, Chennai, Pune, Gurgaon etc. The growth in the service sector in India has been led by the IT-ITES sector, contributing substantially to increase in GDP, employment, and exports. The sector has increased its contribution 
to India's GDP from $6.1 \%$ in $2009-10$ to $6.4 \%$ in $2010-11$. According to NASSCOM, the IT-BPO sector in India aggregated revenues of US\$88.1 billion in FY2011. The top seven cities that account for about $90 \%$ of this sectors exports are Bangalore, Chennai, Hyderabad, Mumbai, Pune, Delhi, Kolkata, Coimbatore and Kochi dominate the IT-ITES industry and constitute about $77 \%$ of the total industry revenue. Though the IT-ITES sector is export driven, the domestic market is also significant with a robust revenue growth. There are thousands of employees working for this sector, for which a better quality of work life is very important to sustain them in the job.

\section{Literature Review}

Various authors and researchers have proposed models of Quality of working life which include a wide range of factors. Selected models are reviewed below. Hackman and Oldham (1976) drew attention to what they described as psychological growth needs as relevant to the consideration of Quality of working life.

Several such needs were identified;

- $\quad$ Skill variety

- $\quad$ Task Identity

They suggested that such needs have to be addressed if employees are to experience high quality of working life. In contrast to such theory based models, Taylor (1979) more pragmatically identified the essential components of Quality of working life as;

1) Extrinsic job factors of wages, hours and working conditions

2) Intrinsic job notions of the nature of the work itself

He suggested that a number of other aspects could be added including;

- $\quad$ individual power

- Employee participation in the management

- Fairness and equity

- Social support

- Use of one's present skills
- $\quad$ Task significance

- Autonomy and feedback
- $\quad$ Self development

- A meaningful future at work

- Social relevance of the work or product

- Effect on extra work activities

Taylor suggested that relevant Quality of working life concepts may vary according to organization and employee group. Warr and colleagues (1979), in an investigation of Quality of working life, considered a range of apparently relevant factors, including

- Work involvement

- Intrinsic job motivation

- Higher order need strength

- Perceived intrinsic job

They discussed a range of correlations derived from their work such as

1) Between work involvement and job satisfaction

2) Intrinsic job motivation and job satisfaction

3) Perceived intrinsic job characteristics and job satisfaction

In particular, Warr et al. found evidence for a moderate association between total job satisfaction and total life satisfaction and happiness, with a less strong but significant association with self-rated anxiety. Thus whilst some authors have emphasized the workplace aspects in Quality of working life, others have identified the relevance of personality factors, psychological well being, and broader concepts of happiness and life satisfaction.Factors more obviously and directly affecting work has however served as the main focus of attention as researchers have tried to tease out the important influences on Quality of working life in the workplace.

Mirvis and Lawler (1984) suggested that Quality of working life was associated with
a) satisfaction with wages
b) hours and working conditions

Describing the "basic elements of a good quality of work life" as;
A)
Safe work environment
C) Equal employment opportunities
B)
Equitable wages 
Baba and Jamal (1991) listed what they described as typical indicators of quality of working life including: Job satisfaction, job involvement, work role ambiguity, work role conflict, work role overload, job stress, organizational commitment and Turn-over intentions.

Baba and Jamal also explored reutilization of job content, suggesting that this facet should be investigated as part of the concept of quality of working life. Sirgy et al. (2001) suggested that the key factors in quality of working life are:

\section{1) Need satisfaction based on job requirements \\ 2) Need satisfaction based on Work environment \\ 3) Need satisfaction based on Supervisory behavior \\ 4) Need satisfaction based on Ancillary programmes \\ 5) Organizational commitment}

Martinsons and Cheung (2001) concluded from their research that frequent changes in work environment directly or indirectly influence the performance and productivity of IT professionals. Indeed the changes in working conditions result in stressful conditions and the employees are still expected to perform under stress. Now the organization needs to have effective coping strategies in place; to handle the after effects of performance under stress.

Beukema (1987) suggested QWL is the extent to which employees are able to shape their jobs actively, in accordance with their options, interests and needs. It is the measure of power given by management to its employees to reshape their work. In other words, an employee has the full freedom to design his job functions commensurate with his personal needs and interests. This definition focuses upon the individual's choice of interest in carrying out the task.

\section{Statement of the Problem}

Studying QWL encompasses benefit to the organization and its workforce. It is the concern of the management to establish and meet certain expectations whether these be making profit or delivering a service efficiently and cost effectively.It is being recognized that reaching organizational goals is not the only responsibility of the management, they also bear the responsibility of the well being of their employees, so that they have committed, involved, responsible and motivated subordinates. Studies find consistent positive relationship between QWL and performance, productivity, dedication, involvement and similarly, QWL connected with health problems and life in general. Hence an attempt is made to provide an overview of research that demonstrates the importance of Quality of Work Life with respect to the following constructs.

1) Job satisfaction

2) Working condition

3) General well being

4) Home work interface /Work life balance and

5) Career prospects, Compensation \& Training and development

\section{Objective of the Study}

1) To study the relationship between demographic factors on QWL

2) To study the interplay between the constructs of QWL

3) To elicit the factors that needs to improve for a better QWL

4) To study the correlation between the items of QWL

To draw an overall idea of employees attitude on the constructs of QWL

\section{Hypothesis}

Ho: The total years of experience of the employee does not have any effect on the constructs of QWL

$\mathrm{H}_{1}$ : The total years of experience of the employee do have an effect on the constructs of QWL

$\mathrm{H}_{0}$ : The gender of the employee does not have any effect on the constructs of QWL

H2: The gender of the employee does have an effect on the constructs of QWL

$\mathrm{H}_{0}$ : The age of the employee does not have any effect on the constructs of QWL 
$\mathrm{H}_{3}$ : The age of the employee do have an effect on the constructs of QWL

$\mathrm{H}_{0}$ : There is no significant relationship between the constructs of QWL

$\mathrm{H}_{4}$ : There is significant relationship between the constructs of QWL

\section{Limitations of the Study}

The study was confined to a limited number of respondents, taken the wide scope of the industry. The response of the respondents is instantaneous and may not disclose the facts as it exists. The time is also a major constraining factor for the conduction of $100 \%$ survey and for the comparative study with another industry. The study was restricted to Bangalore city only.

\section{Research Design}

\subsection{Sampling Method and Sample Size}

For a research study to be perfect the sample size selected should be optimal i.e. it should neither be excessively large nor too small. Here the sample size was bounded to 100. Convenience sampling method is employed for the process of sampling.

\subsection{Software Used}

SPSS and SAS Software's are used for tabulation of data.

\subsection{Tools Used For Analysis}

Frequency and Percentage Analysis: One of the simplest methods of analysis is the percentage method. It is one of the traditional statistical tools. Through the use of percentage the data are reduced in the standard form with the base equal to 100 , which facilitates comparison.

Chi Square Test: In statistics, a likelihood ratio test is a statistical test used to compare the fit of two models, one of which (the null model) is a special case of the other (the alternative model). The test is based on the likelihood ratio, which expresses how many times more likely the data are under one model than the other.

Cronbach's (Alpha): In statistics, Cronbach's (alpha) is a coefficient of reliability. It is commonly used as a measure of the internal consistency or reliability of a psychometric test score for a sample of examinees.

Cronbach's $\alpha$ is defined as

$$
\alpha=\frac{\mathrm{K}}{\mathrm{K}-1}\left(1-\frac{\sum_{\mathrm{i}=1}^{\mathrm{K}} \sigma_{\mathrm{Y}_{\mathrm{i}}}^{2}}{\sigma_{\mathrm{X}}^{2}}\right)
$$

Where $K$ is the number of components (K-items or testlets), $\sigma_{\mathrm{X}}^{2}$ the variance of the observed total test scores, and $\sigma_{\mathrm{Y}_{\mathrm{i}}}^{2}$ the variance of component $I$ for the current sample of persons.

Pearson's Correlation Coefficient, R: Correlation is a technique for investigating the relationship between two quantitative, continuous items, usually labeled $\mathrm{X}$ and $\mathrm{Y}$. In correlation the emphasis is on the degree to which a linear model may describe the relationship between two items. The correlation coefficient may take on any value between plus and minus one.

$$
-1.00 \leq \mathrm{r} \leq+1.00
$$

The sign of the correlation coefficient $(+,-)$ defines the direction of the relationship, either positive or negative. A positive correlation coefficient means that as the value of one variable increases, the value of the other variable increases; as one decreases the other decreases. A negative correlation coefficient indicates that as one variable increases, the other decreases, and vice-versa.

\section{Data Analysis and Intepretation}

The data collected from the survey was analyzed in four stages:

STAGE I: Test of Reliability (Cronbach's Alpha)

STAGE II: Demographic relationship with Constructs of QWL

STAGE III: Correlation among the items of each construct in QWL

STAGE IV: Inter correlation among the constructs of QWL

\section{STAGE I: Statistical Analysis for Test of Reliability}


Table 1. Cronbach's alpha

\begin{tabular}{cc}
\hline CONSTRUCTS & ALPHA VALUE \\
\hline Job satisfaction & 0.9 \\
Working condition & 0.83 \\
General well being & 0.78 \\
Work life balance & 0.67 \\
Career prospects & 0.85 \\
\hline
\end{tabular}

Source: SPSS

From the above table it is clear that Job satisfaction, Working condition, General well being \& Career prospects scales have high level of internal consistency where work life balance scale shows a slightly less consistency.

STAGE II: Demographic Relationship with Constructs of QWL

Table 2. Statistics for age group and job satisfaction

\begin{tabular}{cllll}
\hline S.NO & \multicolumn{1}{c}{ ITEM } & DF & CHI SQUARE & P VALUE \\
\hline 1 & Satisfying work place recognition & 12 & 9.2 & 0.6 \\
2 & Like the work allotted & 12 & 9.4 & 0.6 \\
3 & Able to plan work & 12 & 10.2 & 0.5 \\
4 & Fears about job security & 16 & 37 & $\mathbf{0 . 0 0 2}$ \\
5 & Proud to work for company & 12 & 12.4 & 0.4 \\
6 & Free in method of work & 12 & 12.7 & 0.3 \\
7 & Opportunities provided is good & 12 & 7.5 & 0.8 \\
8 & Main satisfaction comes from work & 12 & 13.2 & 0.3 \\
9 & Happy with the responsibility given & 12 & 18.2 & 0.1 \\
10 & Satisfied with pay structure & 16 & 12.4 & 0.7 \\
\hline
\end{tabular}

Source: SAS

From the above data it is clear that there is significant relationship between age group and fears about job security. Since only one item shows significant in job satisfaction scale out of 10 items the null hypothesis can be accepted and can be concluded that there is no significant relationship between age group and job satisfaction.

Table 3. Statistics for age group and working condition

\begin{tabular}{clccc}
\hline S.NO & \multicolumn{1}{c}{ ITEM } & DF & CHI SQUARE & P VALUE \\
\hline 1 & Pressure to meet deadlines & 16 & 28.8 & $\mathbf{0 . 0 2}$ \\
2 & Work duties interface with personal work & 16 & 25.2 & 0.06 \\
3 & Work load is too heavy & 12 & 12.6 & 0.39 \\
4 & Frequent interruptions at work & 16 & 12.3 & 0.71 \\
5 & Provided with information needed for the job & 12 & 8.4 & 0.74 \\
6 & Not given up activities that enjoy to work & 16 & 9.9 & 0.87 \\
7 & Cleanliness of the buildings, parkings & 12 & 16.2 & 0.1 \\
8 & Child care/crèche facility & 16 & 15 & 0.5 \\
9 & Respect from peer & 8 & 9.2 & 0.3 \\
\hline
\end{tabular}

Source: SAS

From the above data it is clear that there is a marginal significant relationship between age group and pressure to 
meet deadlines. Since there is only marginal significance null hypothesis can be accepted and can be concluded that there is no significant relationship between age group and working condition.

Table 4. Statistics for age group and general well being

\begin{tabular}{cllcc}
\hline S.NO & \multicolumn{1}{c}{ ITEM } & DF & CHI SQUARE & P VALUE \\
\hline 1 & Enough time to sleep every day & 16 & 9.9 & 0.8 \\
2 & Skip breakfast lunch for work often & 16 & 17.8 & 0.3 \\
3 & Feel rushed at work & 16 & 10.5 & 0.8 \\
4 & Change in timings involves lot of stress & 16 & 18.5 & 0.2 \\
5 & Work stress affect social life & 16 & 13.2 & 0.6 \\
6 & Very often get headache or back pain & 16 & 12.1 & 0.7 \\
7 & Difficulties in falling asleep & 16 & 15.2 & 0.5 \\
8 & Depressed because of work or work related problems & 16 & 14.0 & 0.5 \\
\hline
\end{tabular}

Source: $S A S$

From the above data it is evident that there is no significant relationship between age group and general well being, the null hypothesis is accepted accordingly.

Table 5. Statistics for age group and work life balance

\begin{tabular}{rlccc}
\hline S.NO & \multicolumn{1}{c}{ ITEM } & DF & CHI SQUARE & P VALUE \\
\hline 1 & Thinking about work instead of focusing on home activities & 16 & 20.3 & 0.2 \\
2 & Spend as much time in family and family related matter & 12 & 32.6 & $\mathbf{0 . 0 0 1}$ \\
3 & Conflicts in family about working hours & 16 & 21.0 & 0.1 \\
4 & Difficult to concentrate on work because of home matters & 16 & 42.5 & $\mathbf{0 . 0 0 0 3}$ \\
5 & Neglecting home matter because of job & 16 & 26.1 & $\mathbf{0 . 0 5}$ \\
6 & Cope better with children & 16 & 22.4 & 0.12 \\
7 & Personal consequences of workplace stress affect social life & 16 & 23.7 & 0.09 \\
8 & Work from home & 16 & 25.6 & $\mathbf{0 . 0 5}$ \\
\hline
\end{tabular}

Source: $S A S$

From the above data it is clear that there is significant relationship between age group and spending time in family, difficulty in concentrating in work because of home matters, neglecting home matter because of job and work from home. Four items are significant in Work life Balance scale out of 8 items, the null hypothesis is rejected and can be concluded that there is significant relationship between age group and work life balance.

Table 6. Statistics for age group and career prospects, compensation and training and development

\begin{tabular}{rlccc}
\hline S.NO & \multicolumn{1}{c}{ ITEM } & DF & CHI SQUARE & P VALUE \\
\hline 1 & Future looks good & 12 & 7.6 & 0.8 \\
2 & Participate in decision making & 12 & 6.9 & 0.8 \\
3 & Learning new things in job & 12 & 14.5 & 0.2 \\
4 & Fringe benefits are good & 16 & 24.9 & 0.07 \\
5 & Promotions are handled fairly & 12 & 10.5 & 0.5 \\
6 & Opportunities for career progression are good & 12 & 18.8 & 0.09 \\
7 & Satisfied with the training and development & 16 & 22.9 & 0.1 \\
8 & Eager to undertake further training and development & 16 & 11.1 & 0.8 \\
9 & Satisfied with my current pay scale & 16 & 14.0 & 0.5 \\
\hline
\end{tabular}

Source: $S A S$ 
The above table elicits the interpretation by concluding that there is no significant relationship between age group and Career Prospects, Compensation and Training and Development hence null hypothesis is accepted.

Table 7. Statistics for gender and job satisfaction

\begin{tabular}{|c|c|c|c|c|}
\hline S.NO & ITEM & $\overline{\text { DF }}$ & CHI SQUARE & P VALUE \\
\hline 1 & Satisfying work place recognition & 3 & 1.7 & 0.6 \\
\hline 2 & Like the work allotted & 3 & 3.7 & 0.2 \\
\hline 3 & Able to plan work & 3 & 4.5 & 0.2 \\
\hline 4 & Fears about job security & 4 & 9.0 & 0.05 \\
\hline 5 & Proud to work for company & 3 & 4.2 & 0.2 \\
\hline 6 & Free in method of work & 3 & 6.0 & 0.1 \\
\hline 7 & Opportunities provided is good & 3 & 0.5 & 0.9 \\
\hline 8 & Main satisfaction comes from work & 3 & 5.9 & 0.1 \\
\hline 9 & Happy with the responsibility given & 3 & 7.1 & 0.06 \\
\hline 10 & Satisfied with pay structure & 4 & 6.1 & 0.1 \\
\hline
\end{tabular}

Source: SAS

From the above data it is clear that there is no significant relationship between gender and job satisfaction, the null hypothesis can be accepted and can be concluded that there is no significant relationship between gender and job satisfaction.

Table 8. Statistics for gender and working condition

\begin{tabular}{clccc}
\hline S.NO & \multicolumn{1}{c}{ ITEM } & DF & CHI SQUARE & P VALUE \\
\hline 1 & Pressure to meet deadlines & 4 & 7.5 & 0.1 \\
2 & Work duties interface with personal work & 4 & 6.2 & 0.1 \\
3 & Work load is too heavy & 3 & 9.2 & $\mathbf{0 . 0 2}$ \\
4 & Frequent interruptions at work & 4 & 5.1 & $\mathbf{0 . 0 2}$ \\
5 & Provided with information needed for the job & 3 & 6.8 & 0.07 \\
6 & Not given up activities that enjoy to work & 4 & 3.6 & 0.4 \\
7 & Cleanliness of the buildings,parkings & 3 & 3.38 & 0.33 \\
8 & Child care/crèche facility & 4 & 9.8 & $\mathbf{0 . 0 4}$ \\
9 & Respect from peer & 2 & 5.9 & $\mathbf{0 . 0 5}$ \\
\hline
\end{tabular}

Source: SAS

There is significant relationship between gender and work load, frequent interruptions, child care and respect from peer. From the above data 4 items in working condition out of 9 are significant, it can be concluded that there is a marginal relationship between gender and working condition.

Table 9. Statistics for gender and general well being

\begin{tabular}{clccc}
\hline S.NO & \multicolumn{1}{c}{ ITEM } & DF & CHI SQUARE & P VALUE \\
\hline 1 & Enough time to sleep every day & 4 & 24.6 & $<\mathbf{0 . 0 0 0 1}$ \\
2 & Skip breakfast lunch for work often & 4 & 21.6 & $\mathbf{0 . 0 0 0 2}$ \\
3 & Feel rushed at work & 4 & 5.3 & 0.2 \\
4 & Change in timings involves lot of stress & 4 & 6.4 & 0.1 \\
5 & Work stress affect social life & 4 & 12.0 & $\mathbf{0 . 0 1}$ \\
6 & Very often get headache or back pain & 4 & 11.2 & $\mathbf{0 . 0 2}$ \\
7 & Difficulties in falling asleep & 4 & 19.1 & $\mathbf{0 . 0 0 0 7}$ \\
8 & Depressed because of work or work related problems & 4 & 11.5 & $\mathbf{0 . 0 2}$ \\
\hline
\end{tabular}

Source: $S A S$ 
It is clear from the above table that almost 6 items out of 8 in General well being scale shows significant relationship between gender and general well being.The null hypothesis is rejected and the alternate hypothesis is accepted at high level of significance.

Table 10. Statistics for gender and work life balance

\begin{tabular}{rlccc}
\hline S.NO & \multicolumn{1}{c}{ ITEM } & DF & CHI SQUARE & P VALUE \\
\hline 1 & Thinking about work instead of focusing on home activities & 4 & 4.5 & 0.3 \\
2 & Spend as much time in family and family related matter & 3 & 6.9 & 0.07 \\
3 & Conflicts in family about working hours & 4 & 9.0 & 0.06 \\
4 & Difficult to concentrate on work because of home matters & 4 & 8.8 & 0.06 \\
5 & Neglecting home matter because of job & 4 & 9.11 & $\mathbf{0 . 0 5}$ \\
6 & Cope better with children & 4 & 7.7 & 0.09 \\
7 & Personal consequences of workplace stress affect social life & 4 & 11.9 & $\mathbf{0 . 0 1}$ \\
8 & Work from home & 4 & 15.4 & $\mathbf{0 . 0 3}$ \\
\hline
\end{tabular}

Source: $S A S$

From the above data it is clear that there is significant relationship between Gender and Personal consequences of workplace stress affect social life, work from home and neglecting home matter because of job. Since only 3 items are significant in Work life Balance scale out of 8 items it can that concluded that there is slightly marginal relationship between gender and work life balance.

Table 11. Statistics for gender and career prospects, compensation and training and development

\begin{tabular}{rlccc}
\hline S.NO & \multicolumn{1}{c}{ ITEM } & DF & CHI SQUARE & P VALUE \\
\hline 1 & Future looks good & 3 & 8.0 & $\mathbf{0 . 0 4}$ \\
2 & Participate in decision making & 3 & 8.9 & $\mathbf{0 . 0 3}$ \\
3 & Learning new things in job & 3 & 5.2 & 0.1 \\
4 & Fringe benefits are good & 4 & 14.1 & $\mathbf{0 . 0 0 6}$ \\
5 & Promotions are handled fairly & 3 & 12.8 & $\mathbf{0 . 0 0 5}$ \\
6 & Opportunities for career progression are good & 3 & 15.1 & $\mathbf{0 . 0 0 0 1}$ \\
7 & Satisfied with the training and development & 4 & 21.3 & $\mathbf{0 . 0 0 0 3}$ \\
8 & Eager to undertake further training and development & 4 & 4.8 & 0.3 \\
9 & Satisfied with my current pay scale & 4 & 21.0 & $\mathbf{0 . 0 0 0 3}$ \\
\hline
\end{tabular}

Source: $S A S$

It is clear from the above table that almost 7 items out of 9 in career prospects, compensation and training and development scale shows significant relationship. The null hypothesis is rejected and the alternate hypothesis is accepted at high level of significance.

Table 12. Statistics for total years of experience and job satisfaction

\begin{tabular}{cllll}
\hline S.NO & \multicolumn{1}{c}{ ITEM } & DF & CHI SQUARE & P VALUE \\
\hline 1 & Satisfying work place recognition & 12 & 16.9 & 0.1 \\
2 & Like the work allotted & 12 & 19.5 & 0.07 \\
3 & Able to plan work & 12 & 11.1 & 0.5 \\
4 & Fears about job security & 16 & 13.5 & 0.6 \\
5 & Proud to work for company & 12 & 12.9 & 0.3 \\
6 & Free in method of work & 12 & 11.0 & 0.5 \\
7 & Opportunities provided is good & 12 & 12.5 & 0.3 \\
8 & Main satisfaction comes from work & 12 & 9.9 & 0.6 \\
9 & Happy with the responsibility given & 12 & 14.1 & 0.2 \\
10 & Satisfied with pay structure & 16 & 16.3 & 0.4 \\
\hline
\end{tabular}

Source: SAS 
From the above data it is clear that there is no significant relationship between Years of experience and job satisfaction, the null hypothesis is accepted and can be concluded that there is no significant relationship between years of experience and job satisfaction.

Table 13. Statistics for total years of experience and working condition

\begin{tabular}{clccc}
\hline S.NO & \multicolumn{1}{c}{ ITEM } & DF & CHI SQUARE & P VALUE \\
\hline 1 & Pressure to meet deadlines & 16 & 29.3 & $\mathbf{0 . 0 2}$ \\
2 & Work duties interface with personal work & 16 & 20.8 & 0.1 \\
3 & Work load is too heavy & 12 & 28.9 & $\mathbf{0 . 0 0 4}$ \\
4 & Frequent interruptions at work & 16 & 30.5 & $\mathbf{0 . 0 1}$ \\
5 & Provided with information needed for the job & 12 & 13.3 & 0.3 \\
6 & Not given up activities that enjoy to work & 16 & 25.1 & 0.06 \\
7 & Cleanliness of the buildings, parkings & 12 & 17.5 & 0.1 \\
8 & Child care/crèche facility & 16 & 23.3 & 0.1 \\
9 & Respect from peer & 08 & 7.8 & $\mathbf{0 . 0 4}$ \\
\hline
\end{tabular}

Source: $S A S$

It is clear from the above table that almost 4 items out of 9 in working condition scale shows significant relationship between Total years of experience and working condition. The null hypothesis is rejected and the alternate hypothesis is accepted at marginal level of significance.

Table 14. Statistics for total years of experience and general well being

\begin{tabular}{clccc}
\hline S.NO & \multicolumn{1}{c}{ ITEM } & DF & CHI SQUARE & P VALUE \\
\hline 1 & Enough time to sleep every day & 16 & 13.4 & 0.6 \\
2 & Skip breakfast lunch for work often & 16 & 21.3 & 0.1 \\
3 & Feel rushed at work & 16 & 22.1 & 0.1 \\
4 & Change in timings involves lot of stress & 16 & 16.8 & 0.3 \\
5 & Work stress affect social life & 16 & 12.0 & 0.7 \\
6 & Very often get headache or back pain & 16 & 10.8 & 0.8 \\
7 & Difficulties in falling asleep & 16 & 11.4 & 0.7 \\
8 & Depressed because of work or work related problems & 16 & 13.5 & 0.6 \\
\hline
\end{tabular}

Source: $S A S$

From the above data it is clear that there is no significant relationship between Years of experience and general well being, the null hypothesis is accepted and can be concluded that there is no significant relationship between years of experience and general well being.

Table 15. Statistics for total years of experience and work life balance

\begin{tabular}{rlccc}
\hline S.NO & \multicolumn{1}{c}{ ITEM } & DF & CHI SQUARE & P VALUE \\
\hline 1 & Thinking about work instead of focusing on home activities & 16 & 15.1 & 0.5 \\
2 & Spend as much time in family and family related matter & 12 & 13.9 & 0.3 \\
3 & Conflicts in family about working hours & 16 & 26.0 & $\mathbf{0 . 0 5}$ \\
4 & Difficult to concentrate on work because of home matters & 16 & 19.0 & 0.2 \\
5 & Neglecting home matter because of job & 16 & 19.8 & 0.2 \\
6 & Cope better with children & 16 & 23.2 & 0.1 \\
7 & Personal consequences of workplace stress affect social life & 16 & 13.6 & 0.6 \\
8 & Work from home & 16 & 20.2 & 0.2 \\
\hline
\end{tabular}

Source: $S A S$ 
From the above data it is clear that there is no significant relationship between Years of experience and work life balance and hence the null hypothesis is accepted.

Table 16. Statistics for total years of experience and career prospects, compensation and training and development

\begin{tabular}{|c|c|c|c|c|}
\hline S.NO & ITEM & DF & CHI SQUARE & P VALUE \\
\hline 1 & Future looks good & 12 & 10.1 & 0.5 \\
\hline 2 & Participate in decision making & 12 & 11.4 & 0.4 \\
\hline 3 & Learning new things in job & 12 & 12.7 & 0.3 \\
\hline 4 & Fringe benefits are good & 16 & 11.5 & 0.7 \\
\hline 5 & Promotions are handled fairly & 12 & 11.8 & 0.4 \\
\hline 6 & Opportunities for career progression are good & 12 & 12.0 & 0.4 \\
\hline 7 & Satisfied with the training and development & 16 & 14.5 & 0.5 \\
\hline 8 & Eager to undertake further training and development & 16 & 12.0 & 0.7 \\
\hline 9 & Satisfied with my current pay scale & 16 & 20.0 & 0.2 \\
\hline
\end{tabular}

Source: $S A S$

From the above data it is clear that there is no significant relationship between Years of experience and career prospects, compensation and training and development and hence the null hypothesis is accepted.

STAGE III: Correlation among the Items of Each Construct in QWL

Table 17. Statistics for correlation among the items of job satisfaction

\begin{tabular}{|c|c|c|c|c|c|c|c|c|c|c|}
\hline \multicolumn{11}{|c|}{ Pearson Correlation Coefficients, $N=100$} \\
\hline \multicolumn{11}{|c|}{ Prob $>|\mathbf{r}|$ under H0: $\mathbf{R h o}=0$} \\
\hline & q21 & q22 & $\mathbf{q 2 3}$ & q24 & q25 & $\mathbf{q} 26$ & q27 & $\mathbf{q} 28$ & q29 & q210 \\
\hline \multirow[t]{2}{*}{$\mathbf{q 2 1}$} & 1 & 0.7071 & 0.62075 & 0.18167 & 0.49953 & 0.46053 & 0.52273 & 0.42769 & 0.40094 & 0.42508 \\
\hline & & $<.0001$ & $<.0001$ & 0.0705 & $<.0001$ & $<.0001$ & $<.0001$ & $<.0001$ & $<.0001$ & $<.0001$ \\
\hline \multirow[t]{2}{*}{$\mathbf{q 2 2}$} & 0.7071 & 1 & 0.75104 & 0.27978 & 0.6016 & 0.50701 & 0.54703 & 0.55373 & 0.5545 & 0.42553 \\
\hline & $<.0001$ & & $<.0001$ & 0.0048 & $<.0001$ & $<.0001$ & $<.0001$ & $<.0001$ & $<.0001$ & $<.0001$ \\
\hline \multirow[t]{2}{*}{$\mathbf{q 2 3}$} & 0.62075 & 0.75104 & 1 & 0.11066 & 0.45089 & 0.48895 & 0.52228 & 0.5846 & 0.47056 & 0.47948 \\
\hline & $<.0001$ & $<.0001$ & & 0.273 & $<.0001$ & $<.0001$ & $<.0001$ & $<.0001$ & $<.0001$ & $<.0001$ \\
\hline \multirow[t]{2}{*}{ q24 } & 0.18167 & 0.27978 & 0.11066 & 1 & 0.19468 & 0.25891 & 0.33098 & 0.24837 & 0.28191 & -0.03521 \\
\hline & 0.0705 & 0.0048 & 0.273 & & 0.0523 & 0.0093 & 0.0008 & 0.0127 & 0.0045 & 0.728 \\
\hline \multirow[t]{2}{*}{ q25 } & 0.49953 & 0.6016 & 0.45089 & 0.19468 & 1 & 0.73146 & 0.71128 & 0.49705 & 0.54893 & 0.47651 \\
\hline & $<.0001$ & $<.0001$ & $<.0001$ & 0.0523 & & $<.0001$ & $<.0001$ & $<.0001$ & $<.0001$ & $<.0001$ \\
\hline \multirow[t]{2}{*}{$q 26$} & 0.46053 & 0.50701 & 0.48895 & 0.25891 & 0.73146 & 1 & 0.67999 & 0.56703 & 0.56311 & 0.38023 \\
\hline & $<.0001$ & $<.0001$ & $<.0001$ & 0.0093 & $<.0001$ & & $<.0001$ & $<.0001$ & $<.0001$ & $<.0001$ \\
\hline \multirow[t]{2}{*}{ q27 } & 0.52273 & 0.54703 & 0.52228 & 0.33098 & 0.71128 & 0.67999 & 1 & 0.58417 & 0.60937 & 0.48362 \\
\hline & $<.0001$ & $<.0001$ & $<.0001$ & 0.0008 & $<.0001$ & $<.0001$ & & $<.0001$ & $<.0001$ & $<.0001$ \\
\hline \multirow[t]{2}{*}{ q28 } & 0.42769 & 0.55373 & 0.5846 & 0.24837 & 0.49705 & 0.56703 & 0.58417 & 1 & 0.62015 & 0.51329 \\
\hline & $<.0001$ & $<.0001$ & $<.0001$ & 0.0127 & $<.0001$ & $<.0001$ & $<.0001$ & & $<.0001$ & $<.0001$ \\
\hline \multirow[t]{2}{*}{ q29 } & 0.40094 & 0.5545 & 0.47056 & 0.28191 & 0.54893 & 0.56311 & 0.60937 & 0.62015 & 1 & 0.47552 \\
\hline & $<.0001$ & $<.0001$ & $<.0001$ & 0.0045 & $<.0001$ & $<.0001$ & $<.0001$ & $<.0001$ & & $<.0001$ \\
\hline \multirow[t]{2}{*}{ q210 } & 0.42508 & 0.42553 & 0.47948 & -0.03521 & 0.47651 & 0.38023 & 0.48362 & 0.51329 & 0.47552 & 1 \\
\hline & $<.0001$ & $<.0001$ & $<.0001$ & 0.728 & $<.0001$ & $<.0001$ & $<.0001$ & $<.0001$ & $<.0001$ & \\
\hline
\end{tabular}

Source: SAS 
The above data depicts the correlation between the items of Job satisfaction out of which there is negative correlation between fears about job security and pay structure which shows inverse relationship.

Table 18. Statistics for correlation among the items of working condition

\begin{tabular}{|c|c|c|c|c|c|c|c|c|c|}
\hline \multicolumn{10}{|c|}{$\begin{array}{c}\text { Pearson Correlation Coefficients, } N=100 \\
\text { Prob }>|\mathbf{r}| \text { under H0: Rho }=0\end{array}$} \\
\hline & q31 & q32 & q33 & q34 & q35 & $q 36$ & q37 & q38 & q39 \\
\hline q31 & 1.00000 & $\begin{array}{r}0.69390 \\
<.0001\end{array}$ & $\begin{array}{r}0.77703 \\
<.0001\end{array}$ & $\begin{array}{r}0.59963 \\
<.0001\end{array}$ & $\begin{array}{r}0.22798 \\
0.0225\end{array}$ & $\begin{array}{r}0.22944 \\
0.0217\end{array}$ & $\begin{array}{r}0.20032 \\
0.0457\end{array}$ & $\begin{array}{r}0.41522 \\
<.0001\end{array}$ & $\begin{array}{r}0.18420 \\
0.0666\end{array}$ \\
\hline q32 & $\begin{array}{r}0.69390 \\
<.0001\end{array}$ & 1.00000 & $\begin{array}{r}0.76553 \\
<.0001\end{array}$ & $\begin{array}{r}0.66747 \\
<.0001\end{array}$ & $\begin{array}{r}0.17101 \\
0.0889\end{array}$ & $\begin{array}{r}0.26665 \\
0.0073\end{array}$ & $\begin{array}{r}0.16906 \\
0.0927\end{array}$ & $\begin{array}{r}0.25064 \\
0.0119\end{array}$ & $\begin{array}{r}0.06782 \\
0.5025\end{array}$ \\
\hline q33 & $\begin{array}{r}0.77703 \\
<.0001\end{array}$ & $\begin{array}{r}0.76553 \\
<.0001\end{array}$ & 1.00000 & $\begin{array}{r}0.64401 \\
<.0001\end{array}$ & $\begin{array}{r}0.24261 \\
0.0150\end{array}$ & $\begin{array}{r}0.36532 \\
0.0002\end{array}$ & $\begin{array}{r}0.21553 \\
0.0313\end{array}$ & $\begin{array}{r}0.37396 \\
0.0001\end{array}$ & $\begin{array}{r}0.20180 \\
0.0441\end{array}$ \\
\hline q34 & $\begin{array}{r}0.59963 \\
<.0001\end{array}$ & $\begin{array}{r}0.66747 \\
<.0001\end{array}$ & $\begin{array}{r}0.64401 \\
<.0001\end{array}$ & 1.00000 & $\begin{array}{r}0.28839 \\
0.0036\end{array}$ & $\begin{array}{r}0.20542 \\
0.0403\end{array}$ & $\begin{array}{r}0.19264 \\
0.0548\end{array}$ & $\begin{array}{r}0.22150 \\
0.0268\end{array}$ & $\begin{array}{r}0.03514 \\
0.7285\end{array}$ \\
\hline q35 & $\begin{array}{r}0.22798 \\
0.0225\end{array}$ & $\begin{array}{r}0.17101 \\
0.0889\end{array}$ & $\begin{array}{r}0.24261 \\
0.0150\end{array}$ & $\begin{array}{r}0.28839 \\
0.0036\end{array}$ & 1.00000 & $\begin{array}{r}0.38742 \\
<.0001\end{array}$ & $\begin{array}{r}0.31069 \\
0.0017\end{array}$ & $\begin{array}{r}0.31120 \\
0.0016\end{array}$ & $\begin{array}{r}0.36105 \\
0.0002\end{array}$ \\
\hline q36 & $\begin{array}{r}0.22944 \\
0.0217\end{array}$ & $\begin{array}{r}0.26665 \\
0.0073\end{array}$ & $\begin{array}{r}0.36532 \\
0.0002\end{array}$ & $\begin{array}{r}0.20542 \\
0.0403\end{array}$ & $\begin{array}{r}0.38742 \\
<.0001\end{array}$ & 1.00000 & $\begin{array}{r}0.21316 \\
0.0332\end{array}$ & $\begin{array}{r}0.51562 \\
<.0001\end{array}$ & $\begin{array}{r}0.34079 \\
0.0005\end{array}$ \\
\hline $\begin{array}{l}\text { q37 } \\
\text { q37 }\end{array}$ & $\begin{array}{r}0.20032 \\
0.0457\end{array}$ & $\begin{array}{r}0.16906 \\
0.0927\end{array}$ & $\begin{array}{r}0.21553 \\
0.0313\end{array}$ & $\begin{array}{r}0.19264 \\
0.0548\end{array}$ & $\begin{array}{r}0.31069 \\
0.0017\end{array}$ & $\begin{array}{r}0.21316 \\
0.0332\end{array}$ & 1.00000 & $\begin{array}{r}0.47136 \\
<.0001\end{array}$ & $\begin{array}{r}0.34510 \\
0.0004\end{array}$ \\
\hline q38 & $\begin{array}{r}0.41522 \\
<.0001\end{array}$ & $\begin{array}{r}0.25064 \\
0.0119\end{array}$ & $\begin{array}{r}0.37396 \\
0.0001\end{array}$ & $\begin{array}{r}0.22150 \\
0.0268\end{array}$ & $\begin{array}{r}0.31120 \\
0.0016\end{array}$ & $\begin{array}{r}0.51562 \\
<.0001\end{array}$ & $\begin{array}{r}0.47136 \\
<.0001\end{array}$ & 1.00000 & $\begin{array}{r}0.48013 \\
<.0001\end{array}$ \\
\hline q39 & $\begin{array}{r}0.18420 \\
0.0666\end{array}$ & $\begin{array}{r}0.06782 \\
0.5025\end{array}$ & $\begin{array}{r}0.20180 \\
0.0441\end{array}$ & $\begin{array}{r}0.03514 \\
0.7285\end{array}$ & $\begin{array}{r}0.36105 \\
0.0002\end{array}$ & $\begin{array}{r}0.34079 \\
0.0005\end{array}$ & $\begin{array}{r}0.34510 \\
0.0004\end{array}$ & $\begin{array}{r}0.48013 \\
<.0001\end{array}$ & 1.00000 \\
\hline
\end{tabular}

Source: $S A S$

The above data depicts positive correlation between all the items of working condition. This implies direct relationship.

Table 19. Statistics for correlation among the items of general well being

\begin{tabular}{|c|c|c|c|c|c|c|c|c|}
\hline \multicolumn{9}{|c|}{$\begin{array}{c}\text { Pearson Correlation Coefficients, } N=100 \\
\text { Prob }>|\mathbf{r}| \text { under H0: } \text { Rho }=0\end{array}$} \\
\hline & $q 41$ & $q 42$ & $q 43$ & $q 44$ & $q 45$ & $q 46$ & $q 47$ & $q 48$ \\
\hline$q 41$ & 1.00000 & $\begin{array}{r}-0.29197 \\
0.0032\end{array}$ & $\begin{array}{r}-0.07095 \\
0.4830\end{array}$ & $\begin{array}{r}-0.15771 \\
0.1171\end{array}$ & $\begin{array}{r}-0.25461 \\
0.0106\end{array}$ & $\begin{array}{r}-0.32744 \\
0.0009\end{array}$ & $\begin{array}{r}-0.28345 \\
0.0043\end{array}$ & $\begin{array}{r}-0.17344 \\
0.0844\end{array}$ \\
\hline$q 42$ & $\begin{array}{r}-0.29197 \\
0.0032\end{array}$ & 1.00000 & $\begin{array}{r}0.40319 \\
<.0001\end{array}$ & $\begin{array}{r}0.22218 \\
0.0263\end{array}$ & $\begin{array}{r}0.19114 \\
0.0568\end{array}$ & $\begin{array}{r}0.31667 \\
0.0013\end{array}$ & $\begin{array}{r}0.43070 \\
<.0001\end{array}$ & $\begin{array}{r}0.22941 \\
0.0217\end{array}$ \\
\hline$q 43$ & $\begin{array}{r}-0.07095 \\
0.4830\end{array}$ & $\begin{array}{r}0.40319 \\
<.0001\end{array}$ & 1.00000 & $\begin{array}{r}0.48157 \\
<.0001\end{array}$ & $\begin{array}{r}0.40879 \\
<.0001\end{array}$ & $\begin{array}{r}0.43127 \\
<.0001\end{array}$ & $\begin{array}{r}0.37058 \\
0.0001\end{array}$ & $\begin{array}{r}0.31632 \\
0.0013\end{array}$ \\
\hline q44 & $\begin{array}{r}-0.15771 \\
0.1171\end{array}$ & $\begin{array}{r}0.22218 \\
0.0263\end{array}$ & $\begin{array}{r}0.48157 \\
<.0001\end{array}$ & 1.00000 & $\begin{array}{r}0.57412 \\
<.0001\end{array}$ & $\begin{array}{r}0.47920 \\
<.0001\end{array}$ & $\begin{array}{r}0.38380 \\
<.0001\end{array}$ & $\begin{array}{r}0.31868 \\
0.0012\end{array}$ \\
\hline$q 45$ & $\begin{array}{r}-0.25461 \\
0.0106\end{array}$ & $\begin{array}{r}0.19114 \\
0.0568\end{array}$ & $\begin{array}{r}0.40879 \\
<.0001\end{array}$ & $\begin{array}{r}0.57412 \\
<.0001\end{array}$ & 1.00000 & $\begin{array}{r}0.74096 \\
<.0001\end{array}$ & $\begin{array}{r}0.67667 \\
<.0001\end{array}$ & $\begin{array}{r}0.56554 \\
<.0001\end{array}$ \\
\hline$q 46$ & $\begin{array}{r}-0.32744 \\
0.0009\end{array}$ & $\begin{array}{r}0.31667 \\
0.0013\end{array}$ & $\begin{array}{r}0.43127 \\
<.0001\end{array}$ & $\begin{array}{r}0.47920 \\
<.0001\end{array}$ & $\begin{array}{r}0.74096 \\
<.0001\end{array}$ & 1.00000 & $\begin{array}{r}0.78831 \\
<.0001\end{array}$ & $\begin{array}{r}0.61738 \\
<.0001\end{array}$ \\
\hline$q 47$ & $\begin{array}{r}-0.28345 \\
0.0043\end{array}$ & $\begin{array}{r}0.43070 \\
<.0001\end{array}$ & $\begin{array}{r}0.37058 \\
0.0001\end{array}$ & $\begin{array}{r}0.38380 \\
<.0001\end{array}$ & $\begin{array}{r}0.67667 \\
<.0001\end{array}$ & $\begin{array}{r}0.78831 \\
<.0001\end{array}$ & 1.00000 & $\begin{array}{r}0.74901 \\
<.0001\end{array}$ \\
\hline$q 48$ & $\begin{array}{r}-0.17344 \\
0.0844\end{array}$ & $\begin{array}{r}0.22941 \\
0.0217\end{array}$ & $\begin{array}{r}0.31632 \\
0.0013\end{array}$ & $\begin{array}{r}0.31868 \\
0.0012\end{array}$ & $\begin{array}{r}0.56554 \\
<.0001\end{array}$ & $\begin{array}{r}0.61738 \\
<.0001\end{array}$ & $\begin{array}{r}0.74901 \\
<.0001\end{array}$ & 1.00000 \\
\hline
\end{tabular}

Source: $S A S$ 
From the above table it is clearly evident that there is negative correlation between enough time to sleep everyday and all other items in general well being. This shows inverse relationship. All other items show positive correlation.

Table 20. Statistics for correlation among the items of work life balance

\begin{tabular}{|c|c|c|c|c|c|c|c|c|}
\hline \multicolumn{9}{|c|}{ Pearson Correlation Coefficients, $N=100$} \\
\hline \multicolumn{9}{|c|}{ Prob $>|\mathbf{r}|$ under H0: Rho $=0$} \\
\hline & q51 & $\mathbf{q 5 2}$ & q53 & q54 & $\mathbf{q 5 5}$ & q56 & $\mathbf{q 5 7}$ & q58 \\
\hline \multirow[t]{2}{*}{ q51 } & 1.00000 & -0.21412 & 0.50168 & 0.61564 & 0.62923 & -0.17117 & 0.44151 & 0.31157 \\
\hline & & 0.0324 & $<.0001$ & $<.0001$ & $<.0001$ & 0.0886 & $<.0001$ & 0.0016 \\
\hline \multirow[t]{2}{*}{$\mathbf{q 5 2}$} & -0.21412 & 1.00000 & -0.27083 & -0.24214 & -0.24471 & 0.24950 & -0.12215 & 0.05530 \\
\hline & 0.0324 & & 0.0064 & 0.0152 & 0.0141 & 0.0123 & 0.2260 & 0.5847 \\
\hline \multirow[t]{2}{*}{$\mathbf{q 5 3}$} & 0.50168 & -0.27083 & 1.00000 & 0.65372 & 0.63400 & 0.04497 & 0.42278 & 0.15961 \\
\hline & $<.0001$ & 0.0064 & & $<.0001$ & $<.0001$ & 0.6569 & $<.0001$ & 0.1127 \\
\hline \multirow[t]{2}{*}{ q54 } & 0.61564 & -0.24214 & 0.65372 & 1.00000 & 0.75678 & 0.05206 & 0.36265 & 0.26619 \\
\hline & $<.0001$ & 0.0152 & $<.0001$ & & $<.0001$ & 0.6070 & 0.0002 & 0.0074 \\
\hline \multirow[t]{2}{*}{ q55 } & 0.62923 & -0.24471 & 0.63400 & 0.75678 & 1.00000 & 0.12424 & 0.47591 & 0.18243 \\
\hline & $<.0001$ & 0.0141 & $<.0001$ & $<.0001$ & & 0.2181 & $<.0001$ & 0.0693 \\
\hline \multirow[t]{2}{*}{$q 56$} & -0.17117 & 0.24950 & 0.04497 & 0.05206 & 0.12424 & 1.00000 & 0.06871 & 0.14653 \\
\hline & 0.0886 & 0.0123 & 0.6569 & 0.6070 & 0.2181 & & 0.4970 & 0.1457 \\
\hline \multirow[t]{2}{*}{$\mathbf{q 5 7}$} & 0.44151 & -0.12215 & 0.42278 & 0.36265 & 0.47591 & 0.06871 & 1.00000 & 0.00155 \\
\hline & $<.0001$ & 0.2260 & $<.0001$ & 0.0002 & $<.0001$ & 0.4970 & & 0.9878 \\
\hline \multirow[t]{2}{*}{ q58 } & 0.31157 & 0.05530 & 0.15961 & 0.26619 & 0.18243 & 0.14653 & 0.00155 & 1.00000 \\
\hline & 0.0016 & 0.5847 & 0.1127 & 0.0074 & 0.0693 & 0.1457 & 0.9878 & \\
\hline
\end{tabular}

Source: $S A S$

From the above table it is clearly evident that there is negative correlation between

1) Thinking about work instead of focusing on home activities and Spend as much time in family and family related matter

2) Thinking about work instead of focusing on home activities and Cope better with children

3) Spend as much time in family and family related matter and Conflicts in family about working hours

4) Spend as much time in family and family related matter and Difficult to concentrate on work because of home matters

5) Spend as much time in family and family related matter and Neglecting home matter because of job

6) Spend as much time in family and family related matter and Personal consequences of workplace stress affect social life 
Table 21. Statistics for correlation among the items of career prospects, compensation and training and development

\begin{tabular}{|c|c|c|c|c|c|c|c|c|c|}
\hline \multicolumn{10}{|c|}{$\begin{array}{c}\text { Pearson Correlation Coefficients, } N=100 \\
\text { Prob }>|r| \text { under H0: } R h o=0\end{array}$} \\
\hline & $q 61$ & $q 62$ & $q 63$ & q64 & $q 65$ & $q 66$ & $q 67$ & q68 & q69 \\
\hline \multirow[t]{2}{*}{ q61 } & 1.00000 & 0.74662 & 0.58739 & 0.36758 & 0.44386 & 0.33009 & 0.43245 & 0.14045 & 0.44143 \\
\hline & & $<.0001$ & $<.0001$ & 0.0002 & $<.0001$ & 0.0008 & $<.0001$ & 0.1634 & $<.0001$ \\
\hline \multirow[t]{2}{*}{$q 62$} & 0.74662 & 1.00000 & 0.62324 & 0.49970 & 0.53198 & 0.30945 & 0.37081 & 0.16562 & 0.52952 \\
\hline & $<.0001$ & & $<.0001$ & $<.0001$ & $<.0001$ & 0.0017 & 0.0001 & 0.0996 & $<.0001$ \\
\hline \multirow[t]{2}{*}{$q 63$} & 0.58739 & 0.62324 & 1.00000 & 0.62383 & 0.40467 & 0.32914 & 0.28047 & 0.17338 & 0.29792 \\
\hline & $<.0001$ & $<.0001$ & & $<.0001$ & $<.0001$ & 0.0008 & 0.0047 & 0.0845 & 0.0026 \\
\hline \multirow[t]{2}{*}{ q64 } & 0.36758 & 0.49970 & 0.62383 & 1.00000 & 0.51987 & 0.55918 & 0.33041 & 0.23402 & 0.42868 \\
\hline & 0.0002 & $<.0001$ & $<.0001$ & & $<.0001$ & $<.0001$ & 0.0008 & 0.0191 & $<.0001$ \\
\hline \multirow[t]{2}{*}{$q 65$} & 0.44386 & 0.53198 & 0.40467 & 0.51987 & 1.00000 & 0.44329 & 0.55877 & 0.00226 & 0.61734 \\
\hline & $<.0001$ & $<.0001$ & $<.0001$ & $<.0001$ & & $<.0001$ & $<.0001$ & 0.9822 & $<.0001$ \\
\hline \multirow[t]{2}{*}{$q 66$} & 0.33009 & 0.30945 & 0.32914 & 0.55918 & 0.44329 & 1.00000 & 0.57705 & 0.42355 & 0.48181 \\
\hline & 0.0008 & 0.0017 & 0.0008 & $<.0001$ & $<.0001$ & & $<.0001$ & $<.0001$ & $<.0001$ \\
\hline \multirow[t]{2}{*}{$q 67$} & 0.43245 & 0.37081 & 0.28047 & 0.33041 & 0.55877 & 0.57705 & 1.00000 & 0.28812 & 0.50625 \\
\hline & $<.0001$ & 0.0001 & 0.0047 & 0.0008 & $<.0001$ & $<.0001$ & & 0.0037 & $<.0001$ \\
\hline \multirow[t]{2}{*}{ q68 } & 0.14045 & 0.16562 & 0.17338 & 0.23402 & 0.00226 & 0.42355 & 0.28812 & 1.00000 & 0.03431 \\
\hline & 0.1634 & 0.0996 & 0.0845 & 0.0191 & 0.9822 & $<.0001$ & 0.0037 & & 0.7347 \\
\hline \multirow[t]{2}{*}{ q69 } & 0.44143 & 0.52952 & 0.29792 & 0.42868 & 0.61734 & 0.48181 & 0.50625 & 0.03431 & 1.00000 \\
\hline & $<.0001$ & $<.0001$ & 0.0026 & $<.0001$ & $<.0001$ & $<.0001$ & $<.0001$ & 0.7347 & \\
\hline
\end{tabular}

Source: $S A S$

The above data depicts positive correlation between all the items of career prospects, compensation and training and development which implies direct relationship.

STAGE IV: Inter Correlation among the Constructs of QWL

Table 22. Statistical analysis for correlation among constructs QWL

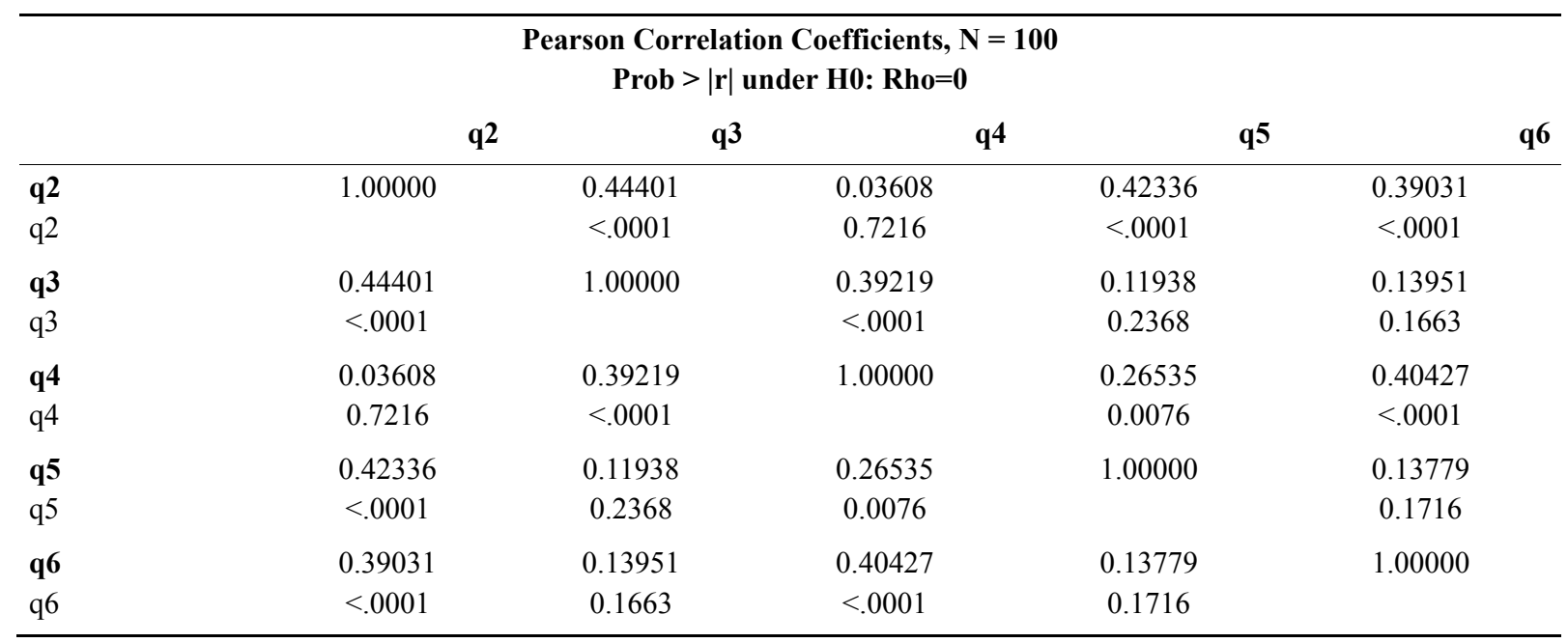

Source: $S A S$ 
From the above table it is clearly evident that there is positive correlation between all the constructs of QWL which implies that each have effect on another.

\section{Findings from the Study}

1) Majority of the respondents are not happy with the pay structure.

2) It is reported that change in timings involves lot of stress.

3) Maximum percentage of the respondents irrespective of their experience has fears about their job security.

4) Majority of the respondents felt that they are neglecting home matter because of work.

5) Though work from home option is provided by majority of the companies the data reports

Dissatisfactory results

6) It is clearly evident from the inter correlation matrix that majority of the employees are not able to spend as much time in family and family related matter.

7) The study also elicits that male respondents are more satisfied towards career prospects, compensation and training and development and have a better work life balance than female respondents because of their family commitment and health related issues.

\section{Conclusion}

In this study, the relationship between gender, age and work experience with QWL were investigated. Further correlation is done to see the effect of constructs on QWL. The majority of IT staffs (about 75\%) are having medium QWL level. Intervention is needed in the identified problem areas. It is recommended that the result of this research serves as a baseline and as a point of comparison after changes have been implemented to assess for a better QWL.

It was suggested that a psychologically healthy work environment is one in which the individual needs are fulfilled and that organizational members experience quality of work life that they regard as important are satisfactory. Therefore the attention was focused on those facets that are seen as possible problem areas and certain suggestions were made.

\section{Suggestions}

It is clearly evident from the correlation study between constructs that if job satisfaction increases working condition, general well being, worklife balance and career prospects, compensation and training and development also increases to a greater extent and vice versa. A fair pay structure, clearcut work from home facility, proper and defined timings and developing employee commitment by providing job security may to a greater extent influence QWL for a better quality of work life.

\section{References}

Baba, V. V., \& Jamal, M. (1991). Routinisation of job context and job content as related to employee's quality of working life: a study of psychiatric nurses. Journal of organizational behavior, 12, 379-386. http://dx.doi.org/10.1002/job.4030120503

Bearfield, S. (2003). Quality of Working Life. Aciirt Working paper 86. University of Sydney.

Beukema, L. (1987). Kwaliteit Van De Arbeidstijdverkorting [Quality of reduction of working hours]. Groningen: Karstapel.

Ellis, N., \& Pompli, A. (2002). Quality of working life for nurses. Commonwealth Dept of Health and Ageing. Canberra.

Hackman, J., \& Oldham, G. (1974). The Job Diagnostic Survey. New Haven: Yale university.

Mirvis, P. H., \& Lawler, E. E. (1984). Accounting for the Quality of Work Life. Journal of Occupational Behavior, 5, 197-212. http://dx.doi.org/10.1002/job.4030050304

Morrison, R. F., \& Holzbach, R. L. (1980). The career manager role. In C. B. Derr (Ed.), Work, Family, and the Career. New York: Praeger Professionals.

Rethinam, G., \& Ismail, M. (n. d.). Constructs of Quality of Work Life: A Perspective of Information and Technology.

Schoepke, J., Hoonakker, P. L. T., \& Carayon, P. (2004). Quality of Working Life among Women and Men in the Information Technology Workforce. Human Factors and Ergonomics Society Annual Meeting Proceedings", 
Macroergonomics, pp. 1576-1580(5). http://dx.doi.org/10.1177/154193120404801404

Sirgy, M. J., Efraty, D., Siegel, P., \& Lee, D. (2001). A new measure of quality of work life (QoWL) based on need satisfaction and spillover theories. Social Indicators Research, 55, 241-302. http://dx.doi.org/10.1023/A:1010986923468

Suzanne, E. J., Arts, A. K., Zee, J. V. D., \& Saad, H. H. A. (Eds.). (2001). Quality of Working Life and Workload in Home Help Services: A Review of the Literature and a Proposal for a Research Model. Scandinavian Journal of Caring Society, 15.

Taylor, J. C., Cooper, C. L., \& Mumford, E. (1979). The quality of working life in Western and Eastern Europe. ABP.

Warr, P., Cook, J., \& Wall, T. (1979). Scales for the measurement of some work attitudes and aspects of psychological well being. Journal of Occupational Psychology, 52, 129-148. http://dx.doi.org/10.1111/j.2044-8325.1979.tb00448.x

\section{Copyrights}

Copyright for this article is retained by the author(s), with first publication rights granted to the journal.

This is an open-access article distributed under the terms and conditions of the Creative Commons Attribution license (http://creativecommons.org/licenses/by/3.0/). 